\title{
KAJIAN CURCUMIN PADA KUNYIT DAN TEMULAWAK DALAM PENYEMBUHAN PENYAKIT CORONAVIRUS DISEASES 2019 (COVID-19)
}

\author{
Tengku Muhammad Fauzi
}

Dosen Tetap Fakultas Kedokteran Methodist Indonesia, Medan, Indonesia

Email: zifirstfauzi@gmail.com

DOI: https://doi.org/10.46880/methoda.Vol11No2.pp138-144

\begin{abstract}
Handling in healing the COVID-19 disease continues to develop, especially in the discovery of herbal medicines that are alternatives to increase the patient's body immunity. Studies from qualitative analysis of several types of rhizome plants such as: turmeric and temulawak show that they contain curcuminoid metabolites. Literature studies show that curcumin compounds are known to act as anti-inflammatory by inhibiting the release of compounds that cause inflammation, also known as pro-inflammatory cytokines, such as Interleukin-6, Interleukin-1 and TNF-Alpha. By inhibiting the release of cytokines, it is hoped that there will be no cytokine storm that can cause respiratory problems in COVID19 sufferers. With this study, it can be used for the use of rhizome types such as turmeric and temulawak, which are expected to be supporters in the healing of coronavirus diseases 2019 (COVID-19).
\end{abstract}

Keyword: Curcumin, COVID-19, Turmeric, Anti-Inflammatory, Antioxidant.

\begin{abstract}
ABSTRAK
Penanganan dalam penyembuhan penyakit COVID-19 terus berkembang, terutama dalam penemuan obat herbal yang menjadi alternatif untuk meningkatkan imunitas tubuh penderta. Kajian dari analisis kualitatif beberapa jenis tanaman rimpang seperti: kunyit dan temulawak menunjukkan memliki kandungan senyawa metabolit Curcuminoid. Studi literatur menunjukkan Senyawa curcumin diketahui berperan sebagai anti inflamasi dengan menghambat pelepasan senyawa penyebab peradangan dikenal juga dengan nama sitokin proinflamasi seperti, Interleukin-6, Interleukin-1 dan TNF-Alpha. Dengan penghambatan pengeluaran sitokin, maka diharapkan tidak terjadi badai sitokin yang dapat menyebabkan gangguan pernapasan pada penderita COVID-19. Dengan adanya kajian ini dapat dgunakan untuk pemanfaatan tanaman jenis rimpang seperti kunyit dan temulawak diharapkan menjadi pendukung dalam penyembuhan penyakit coronavirus diseases 2019 (COVID-19).
\end{abstract}

Kata Kunci: Kurkumin, COVID-19, Kunyit, Anti Inflamasi, Antioksidan.

\section{PENDAHULUAN}

Kurkumin sendiri mempunyai beberapa manfaat misalnya menjadi anti inflamasi menggunakan penghambatan molekul yg memiliki peran terhadap peradangan termasuk lipooxigenase, tromboksan, molekul prostaglandin, molekul oksida nitrat, kolagenase, elastase, hyaluronidase, MCP-1 COX-2, leukotriene, fosfolipase, interferon- inducible protein, factor nekrosis tumor, \& interleukin-12 (Chainani-Wu, 2003).

Peran dari antioksidan kurkumin dalam menangkal peroksidasi lipid terjadi pada beberapa studi model hewan coba. Kurkumin merupakan senyawa antioksidan yg sangat larut pada lemak, pada membran sel, kurkumin akan melakukan reaksi bersama radikal lipid \& membuat radikal fenoksil (Sreejayan \& Rao, 1994). 
Diketahui semenjak epidemi SARS tahun 2003, reseptor SARS-CoV-2 merupakan angiotensinconverting enzyme dua (ACE2). Diketahui ada ACE2 yang bisa berada pada bentuk fixed (melekat pada sel) \& terdapat juga yg soluble (tidak melekat dalam sel) atau soluble ACE2. Penelitian terhadap senyawa kurkumin (menjadi senyawa tunggal atau murni) dilaporkan dapat menimbulkan peningkatan ACE2 pada hewan uji tikus, tetapi belum terdapat penelitian tentang hubungan secara langsung dengan infeksi virus corona. Bagi kegunaan terapi menggunakan kurkumin dapat mempengaruhi lebih banyak ACE2 yang bebas (soluble) diharapkan dapat mencegah virus corona melekat dalam sel, yg secara langsung akan mencegah terjadinya infeksi

Berdasarkan bukti ilmiah yang ada penulis tertarik untuk membahas kajian curcumin yang terdapat pada kunyit dan temulawak dalam mendukung penyembuhan penyakit Coronavirus Diseases 2019 (COVID-19).

\section{TINJAUAN PUSTAKA}

\section{Inflamasi}

Inflamasi merupakan reaksi tubuh terhadap benda asing yg masuk ke pada tubuh, kerusakan jaringan akibat infeks mikroorganisme, bahan kimia yg berbahaya $\&$ faktor fisik (Bratawidjaja, 2000). Inflamasi (radang) umumnya dibagi pada tiga fase, yaitu inflamasi akut, respon imun, \& inflamasi kronis.

Bentuk Inflamasi akut adalah respon awal terhadap terjadinya kerusakan jaringan, Kondisi ini didahului oleh pembentukan respon imun. Respon imun dapat terbentuk bila sejumlah sel yang memiliki kemampuan menimbulkan kondisi kekebalan diaktifkan untuk membuat terjadinya organisme asing atau substansi antigenik yang terlepas selama respon terhadap inflamasi akut maupun kronis. Inflamasi kronis dapat terjadi karena keluarnya sejumlah mediator yang tidak menonjol dalam respon akut. Salah satu dari kondisi yang perannya menjadi penting melibatkan mediator-mediator ini ialah artritis reumatoid, dimana inflamasi kronis menyebabkan gangguan kesehatan dan kerusakan pada tulang dan tulang rawan yang bisa mengarah kepada ketidakmampuan untuk bergerak dimana terjadi perubahan-perubahan sistematik yang bias memperpendek umur (Katzung, 2002). Gejala terjadinya tahapans inflamasi yang umum dikenal adalah kalor (panas), rubor (merah), tumor (bengkak), dolor (gejala sakit), dan functiolaesa (hilangnya fungsi) (Wilmana, 1995). Kondisi akibat membran sel mengalami perubahan oleh suatu rangsangan kimia fisika, atau mekanik, selanjutnya enzim fosfolipase diaktifkan dengan mengubah fosfolipida yang terdapat di membran menjadi asam arakidonat. Asam lemak poli tak jenuh ini, selanjutnya untuk sebagian diubah menjadi enzim siklooksigenase dan seterusnya menjadi zat-zat prostaglandin. Bagian lain dari arakidonat diubah oleh enzim lipoksigenase menjadi zat-zat leukotrien. Senyawa prostaglandin serta leukotrien bertanggung jawab bagi sebagian besar dari gejala peradangan. Peroksida menghasilkan radikal bebas oksigen memiliki peran pada timbulnya rasa nyeri (Tjay \& Rahardja, 2002)

\section{Antioksidan}

Antioksidan merupakan senyawa atau bahan yang dibutuhkan pada jumlah lebih sedikit dari substratnya secara signifikan bertujuan agar tidak terjadi oksidasi. Antioksidan memiliki aktivitas senyawa dengan ciri khas yang menghambat senyawa senyawa radikal agar tidak terbentuk di dalam tubuh. Antioksidan merupakan substansi yang dibutuhkan oleh tubuh dalam menetralisir radikal bebas dan melindungi kerusakan yang ditimbulkan oleh radikal bebas terhadap sel normal (Siahaan, Anto, \& Fauzi, 2021). Anti-oksidan memiliki kemampuan menyeimbangkan senyawa radikal bebas dengan membuat lengkap kekurangan 5 elektron yang dimiliki radikal bebas dan dapat menghambat terjadinya reaksi berantai dari pembentukan radikal bebas. Senyawa antioksidan yang bersifat natural pada tumbuhan umumnya adalah senyawa fenolik atau polifenolik yang dapat berupa golongan flavonoid. Antioksidan dalam pengertian kimia, merupakan senyawa pemberi elektron. Antioksidan bekerja dengan cara mendonorkan satu elektronnya kepada senyawa yang bersifat 
oksidan sehingga aktivitas senyawa oksidan tersebut bisa terhambat. Antioksidan menstabilkan radikal bebas dengan melengkapi kekurangan elektron yang dimiliki radikal bebas, dan menghambat terjadinya reaksi berantai dari pembentukan radikal bebas. Secara fisiologis senyawa fenolik mempunyai beberapa aktivitas biologis, seperti antialergi, antiinflamasi, antimikroba, antioksidan, antitrombotik dan kardioprotektif (Aberoumand \& Deokule, 2008).

\section{Aktivitas Antioksidan Ekstrak Kunyit}

Aktivitas Antioksidan Ekstrak Kunyit dilakukan dengan Metode TBA Untuk mengetahui kemampuan antioksidan menghambat laju reaksi pembentukan malonaldehid acid (MDA) pada proses oksidasi lipida digunakan uji thiobarburic acid (TBA). (Siahaan, 2017). Hasil pengamatan pada aktivitas antioksidan pada metode uji thiobarburic acid (TBA) dengan perbedaan konsentrasi yang secara berturut-turut adalah konsentrasi $0 \%, 10 \%, 30 \%, 50 \%, 70 \%$ dan $90 \%$. Makin besar absorbans pada pengujian TBA, makin kecil aktivitas antioksidan yang disuplementasikan pada asam linoleat. Hasil menunjukkan penambahan ekstrak kunyit mampu menghambat pembentukan MDA. Hal ini terlihat dari perbandingan control (tidak diberi ekstrak kunyit) dengan beberapa perlakuan ekstrak kunyit. Pada perlakuan dengan konsentrasi etanol $90 \%$ dan suhu pengeringan $60^{\circ} \mathrm{C}$ hampir mendekati BHT (antioksidan sitetik). Hal ini disebabkan pada perlakuan tersebut aktivitas antioksidan mampu menghambat terbentuknya MDA yang terjadi pada masa inkubasi (Suhendra, 2017).

\section{Aktivitas Antioksidan Ekstrak Temulawak}

Penentuan aktivitas antioksidan ditunjukkan dengan keberhasilan ekstrak temulawak dalam proses penghambatan radikal bebas. Peranan penting senyawa antioksidan dalam proses penghambatan terhadap pengaruh senyawa radikal bebas yang buruk bagi tubuh. Antioksidan yang ada di uji aktivitasnya dalam metode DPPH. Metode ini didasarkan pada kemampuan antioksidan dalam proses penghambatan radikal bebas dengan memberikan atom hidrogen. Menunjukkan dari hasil penelitian pada ekstrak temulawak dengan nilai IC50 sebesar 87,01 ppm. Nilai pada IC50 yang didapatkan menunjukkan bahwa ekstrak temulawak dapat menangkap radikal bebas DPPH 50\% pada konsentrasi 87,01 ppm. Kondisi niali yang semakin rendah pada IC50 suatu bahan, maka akan menjadi semakin tinggi aktivitas senyawa antikosidan tersebut.

Dengan metode DPPH aktifitas antioksidan dapat terjadi oleh karena terdapat komponen aktif dalam ekstrak temulawak. Kemampuan komponen aktif sebagai oksidan dan radikal akan diubah menuju bentuk yang seimbang dengan mekanisme transfer elektron. Gugus reaktif pada DPPH (1,1-difenil-2- pikrilhidrazil) adalah gugus nitrogen dapat berpasangan dengan atom hidrogen pada antioksidan menjadikan terbentuknya radikal DPPH yang seimbang $(1,1-$ difenil-2-pikrilhidrazin). Kemampuan anti oksidan dalam ekstrak temulawak untuk menyerap radikal DPPH diperlihatkan dengan terjadinya perubahan warna. Proses terjadinya penurunan intensitas warna dapat dilakukan melalui mekanisme transfer elaktron tunggal yang membuat terjadinya peluruhan warna DPPH dari ungu menjadi kuning. Semakin banyak elektron yang diberikan, maka kondisi warna ungu membuat makin emudar dan mendekati warna kuning-cokelat, sebagai penunjuk konsentrasi yang tinggi dari senyawa antioksidan di dalam ekstrak. Kerja dari senyawa antioksidan dengan metode DPPH berdasarkan adanya penyerapan radikal DPPH oleh senyawa antioksidan pada kstrak rimpang temulawak. DPPH merupakan radikal bebas yang seimbang dalam larutan memiliki air atau larutan metanol dan serapannya yang kuat pada panjang gelombang $517 \mathrm{~nm}$ (Rosiyani, 2010).

\section{Virologi Coronavirus}

Coronavirus merupakan virus RNA memiliki ukuran partikel 120-160 $\mathrm{nm}$. Virus terutama menginfeksi hewan, termasuk di antaranya adalah kelelawar dan unta. Pada kondisi Sebelum terjadinya wabah COVID-19, ada 6 jenis coronavirus yang memiliki kemampuan menginfeksi manusia, yaitu alphacoronavirus 229E, alphacoronavirus NL63, betacoronavirus 
OC43, betacoronavirus HKU1, Severe Acute Respiratory Illness Coronavirus (SARS-CoV), dan Middle East Respiratory Syndrome Coronavirus (MERS-CoV) (Riedel, Morse, Mietzner, \& Miller, 2019). Coronavirus yang menjadi etiologi COVID-19 merupakan termasuk dalam genus betacoronavirus. Pada data analisis filogenetik memberikan informasi virus ini termasuk kedalam subgenus yang mirip dengan coronavirus yang mengakibatkan wabah Severe Acute Respiratory Illness (SARS) pada 2002-2004 silam, yaitu Sarbecovirus. Atas dasar ini, International Committee on Taxonomy of Viruses mengajukan nama SARS-CoV-2 (Gorbalenya et al., 2020).

\section{Patogenesis Coronavirus}

Proses terjadinya respons imun oleh SARSCoV-2 masih belum sepenuhnya untuk dapat dipahami, namun bias untuk dilakukan proses pembelajaran dari mekanisme yang ditemukan pada SARS-CoV dan MERS-CoV. Pada saat virus masuk ke dalam sel, antigen virus yang muncul dipresentasikan ke antigen presentation cells (APC). Presentasi antigen virus bergantung utamanya pada molekul major histocompatibility complex (MHC) kelas I. Namun, MHC kelas II juga turut berkontribusi (Gambar 1) (Li, Geng, Peng, Meng, \& Lu, 2020) Selanjutnya presentasi antigen dapat merangsang respons imunitas humoral dan selular tubuh dengan mediasi oleh sel $\mathrm{T}$ dan sel B yang spesifik terhadap virus. Pada respons imun humoral terbentuk IgM dan IgG terhadap SARS-CoV. IgM terhadap SAR-CoV menjadi hilang pada akhir minggu ke-12 dan IgG dapat dengan kondisi memilik daya tahan jangka panjang. Penelitian pada pasien yang telah sembuh dari SARS terdapat penunjuk setelah 4 tahun dijumpai sel T CD4+ dan CD8+ memori yang bentuknya spesifik terhadap SARS-CoV, namun jumlahnya dapat terjadi penurunan secara bertahap dengan tidak adanya antigen (Fan et al., 2009).

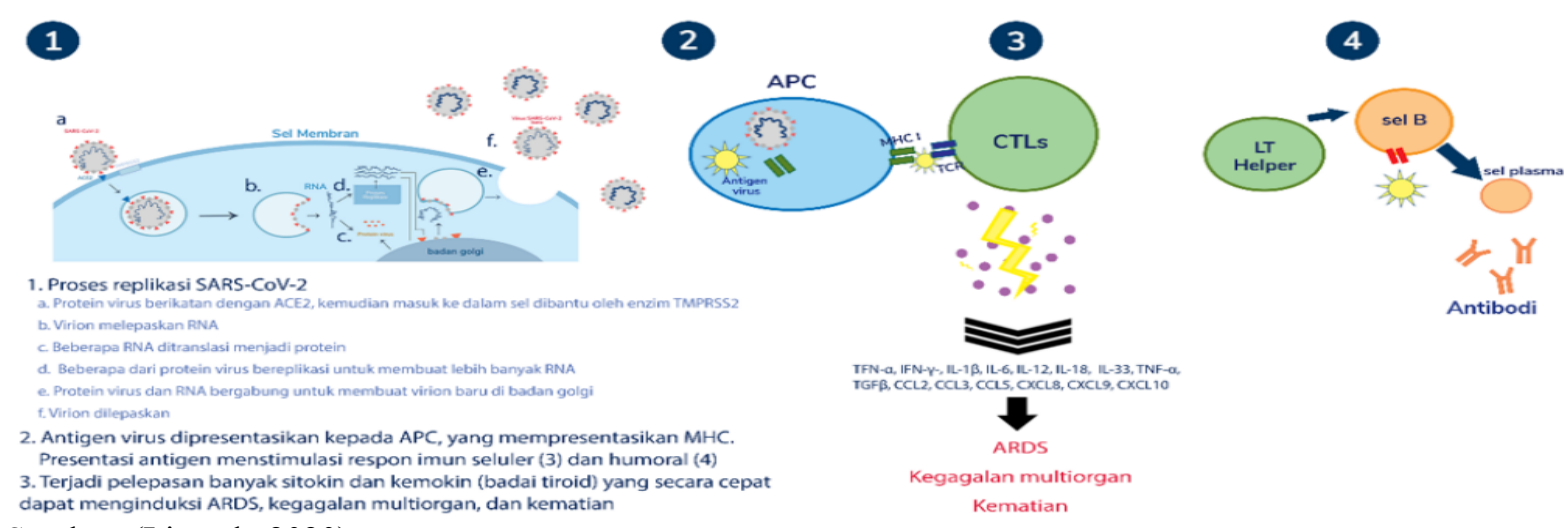

Sumber: (Li et al., 2020)

Gambar 1. Skema Replikasi Dan Patogenesis Virus

Virus mempunyai proses untuk dapat menghindar dari respons imun pejamu. SARS$\mathrm{CoV}$ memiliki kemampuan memberikan induksi dalam produksi vesikel membran ganda yang tidak memiliki pattern recognition receptors (PRRs) dan memiliki memampuan replikasi dalam vesikel tersebut sehingga tidak dapat dikenali oleh pejamu. Jalur IFN-I juga diinhibisi oleh SARS-CoV dan MERS-CoV. Presentasi antigen juga terhambat pada infeksi akibat MERS-CoV (Li et al., 2020).

\section{PEMBAHASAN}

\section{Manfaat Senyawa Kurkumin Pada Kunyit Dan Temulawak}

Kurkumin adalah senyawa turunan fenol yang dijumpai pada kunyit dan temulawak lebih banyak. Pigmen kurkumin tersebut terlarut dalam pelarut polar seperti etanol, karena adanya tingkat kepolaran kurkumin mirip dengan etanol 95\%. (Pokorny et.al., 2001). Perubahan rasio aseton $70 \%$ dari 1:5 menjadi 1:10 dapat memberikan peningkatan dari ekstraksi tanin 
yang terkondensasi Canola meal dengan fenol total dari 773,5 menjadi 805,8 per $100 \mathrm{~g}$ meal. Aan dalam penelitiannya menginformasikan rasio bahan baku pelarut aseton 1:8 dapat membuat hasil kurkumin $0,99-1,39 \%$ yaitu lebih tinggi dibanding rasio $1: 5(0,93-1,25 \%)$ (Aan, 2004). Dari beberapa hasil penelitian tersebut posisi hubungan pelarut dan bahan yang terekstraksi adalah pada posisi meningkat atau semakin banyak pelarut bahan yang terekstraksi semakin besar.

Ekstrak air Kunyit memberikan aktivitas imunostimulan dengan melalui uji in vitro pada sel darah manusia (peripheral blood mononuclear cells (PBMC)). Hal tersebut dilihat dari hasil pengujian, yaitu berupa peningkatan sitokin pro-inflamasi secara signifikan $\left({ }^{*} \mathrm{p}<0.05\right.$, $* * p<0.05)$ seperti TNF- $\alpha$ pada pemberian konsentrasi $400^{*}$ dan $800^{* *} \mathrm{pg} / \mathrm{mL}$. Sitokin proinflamasi lainnya yang meningkat adalah IL6 pada pemberian konsentrasi $400 *$ dan $800 *$ $\mathrm{pg} / \mathrm{mL}$. Peningkatan kadar kedua sitokin tersebut dibandingkan dengan sel yang tidak diberikan intervensi. Penelitian ini juga melakukan pengujian pada fraksi etil asetat, nbutanol, dan etanol. Namun, karena ekstrak air memberikan respon yang paling baik terhadap poliferasi PBMC, maka hanya disebutkan hasil dari intervensi ekstrak air (Yue et al., 2010).

Selain sebagai imnostimulan, kunyit dapat memiliki aktivitas imunosupresan melalui mekanisme antiinflamasi serta digunakan sebagai pencegah penyakit-penyakit inflamasi kronis seperti alergi, asma, dan lainnya (Aggarwal \& Harikumar, 2009).

Pemberian kurkumin pada mencit yang terinfeksi dapat menurunkan sitokin proinflamasi seperti TNF- $\alpha$ dan IFN- $\gamma$ serta meningkatkan sitokin antiinflamasi seperti IL-10 dan IL-4 dibandingkan dengan kelompok yang tidak diberi kurkumin. Pengujian tersebut dilakukan dengan kurkumin pada dosis 3, 10, dan $30 \mathrm{mg} / \mathrm{kg}$, dimana ketiga dosis tersebut menunjukan aktivitas antiparasit yang signifikan (p) dibandingkan dengan kelompok yang tidak diberi kurkumin (Ali, Sudi, Basir, Embi, \& Sidek, 2017).

Kemudian, ekstrak air kunyit yang diberikan secara topikal (2g/tikus) selama 28 hari menyebabkan penurunan $\mathrm{CD}_{4}+, \mathrm{CD} 8+$, serta natural killer cell pada tikus model tumor pada kulit. Penurunan tersebut dibandingkan dengan tikus yang tidak diberikan ekstrak air kunyit Invalid source specified. Kemampuan kunyit sebagai imunosupresan lainnya ditunjukkan dengan adanya kondisi turunnya kejadian eritema, lesi, serta inflamasi pada pasien dengan psoriasis. Akibat terjadinya penurunan gejala dari psoriasis tersebut yang terjadi pada pasien psoriasis terbagi atas 2 kelompok, dengan kelompok satu minum tonik kunyit dan kelompok kedua mengonsumsi plasebo masingmasing selama 9 minggu. Gejala ini terjadi proses yang menurun serta menjadikan naiknya ualitas hidup secara signifikan pada kelompok tonik kunyit jika dibandingkan dengan kelompok yang hanya menerima plasebo (Bahraini et al., 2018). Mekanisme pada pasien kondisi tersebut diketahui karena adanya penurunan kadar mediator inflamasi seperti TNF- $\alpha$, IL-1 $\beta$, serta IL-6 (Arora, Shah, \& Pandey-Rai, 2016).

Aktivitas imunomodulator dari temulawak juga dapat diketahui dengan melihat adanya proses berubahnya proliferasi limfosit yang telah diisolasi dari limpa mencit jantan galur Balb/c. Seperti yang diketahui jika suatu jaringan terjadi paparan oleh antigen yang tepat, maka limfosit yang berasal dari jaringan limfoid akan dapat berproliferasi dan menyebabkan pelepasan banyak sel $\mathrm{T}$ yang teraktivasi bersamaan antibodi. Organ limpa yang digunakan dalam penelitian diakrenakan merupakan organ limfoid sekunder yang berperan untuk tempat terjadinya respon imun pada antigen yang masuk melalui sirkulasi darah, fungsi lain juga menghasilkan limfosit yang sudah tidak mengalami diferensiasi sehingga keadaan ini akan lebih mudah dalam proses pengamatan terhadap limfosit. Fungsi lain dari organ limpa terutama terlibat dalam perlindungan tubuh terhadap penyakit dan menghasilkan antibody.

\section{Respon imun badai sitokin pada infeksi SARS-CoV-2}

Infeksi virus SARS-CoV-2, dimulai sebagai infeksi virus sederhana kemudian menjadi tidak terkendali setelah beberapa saat dan terus 
berlanjut terjadinya kematian dengan adanya badai sitokin dan kerusakan organ yang serius. Contoh proses terjadinya badai sitokin; imunitas bawaan adalah mekanisme pertahanan yang terpelihara dengan baik untuk pengenalan dan kontrol patogen dan respon imun adaptif. Pemicu imunitas bawaan yang memadai bergantung pada pendeteksian pola molekuler patogen (PAMP: pathogenic molecular patterns) melalui reseptor (PRRs: Pattern recognition receptors), termasuk reseptor (TLR: toll-like receptors), reseptor Rig-I-Like Receptor (RLR), reseptor nod-like receptor (NLR) dan lain lain (Frieman, Heise, \& Baric, 2008).

Status kekebalan bawaan dari pasien yang terinfeksi SARS-CoV-2. Dalam satu laporan di mana 99 kasus di Wuhan diperiksa, peningkatan total neutrofil (38\%), limfosit total berkurang (35\%), peningkatan serum IL-6 (52\%) dan peningkatan protein c-reaktif (84\%) terdeteksi. Peningkatan neutrofil dan penurunan limfosit juga dikaitkan dengan keparahan penyakit dan mortalitas pada pasien COVID-19. Selain itu, pasien dengan perawatan ICU meningkatkan kadar plasma dari beberapa sitokin bawaan IP10, MCP-1, MIP-1A, dan TNF $\alpha$. Karakteristik klinis ini menunjukkan keterlibatan status proinflamasi dalam perkembangan dan keparahan penyakit. Peningkatan serum sitokin proinflamasi pada awal infeksi SARS-CoV dan MERS-CoV, menunjukan keparahan penyakit yang dimediasi oleh badai sitokin serupa dengan SARS-CoV-2. Respon imun bawaan yang kuat terhadap infeksi virus sangat bergantung pada respon interferon (IFN) tipe I dan kaskade yang melengkapi dalam mengelola replikasi virus dan inisiasi respon imun adaptif yang efektif (Huang et al., 2020).

\section{KESIMPULAN}

Dengan adanya keterkaitan kurkumin dengan COVID-19, penggunaan tanaman kunyit dan temulawak dengan cara tunggal maupun bersamaan memberikan bantuan dalam peningkatan kemampuan ketahanan tubuh atau dikenal sebagai imunomodulator. Oleh karena itu, pemanfaatan kunyit dan temulawak dapat sebagai jamu, obat herbal terstandarkan, atau suplemen minuman memiliki manfaat yang baik bagi tubuh. Untuk penyembuhan COVID-19 diperlukan pembuktian dan penelitian yang lanjut, terutama kerja keras dari berbagai pihak antara lain: peneliti, perusahaan farmasi, dan juga pemerintah Indonesia terutama usaha pengembangan tanaman tanaman tersebut sehingga memberikan kemampuan menjadikan kunyit dan temulawak obat fitofarmaka yang perannya sebagai antivirus pada penyakit COVID-19.

\section{DAFTAR PUSTAKA}

Aan. (2004). Pengaruh Waktu, Suhu dan Nisbah Bahan BakuPelarut pada Ekstraksi Kurkumin dari Temulawak dengan Pelarut Aseton. Institut Pertanian Bogor.

Aberoumand, A., \& Deokule, S. S. (2008). Comparison of phenolic compounds of some edible plants of Iran and India. Pakistan Journal of Nutrition, 7(4), 582585

Aggarwal, B. B., \& Harikumar, K. B. (2009). Potential therapeutic effects of curcumin, the anti-inflammatory agent, against neurodegenerative, cardiovascular, pulmonary, metabolic, autoimmune and neoplastic diseases. The International Journal of Biochemistry \& Cell Biology, 41(1), 40-59.

Ali, A. H., Sudi, S., Basir, R., Embi, N., \& Sidek, H. M. (2017). The Antimalarial Effect of Curcumin Is Mediated by the Inhibition of Glycogen Synthase Kinase-3 3. Journal of Medicinal Food, 20(2), 152161.

Arora, N., Shah, K., \& Pandey-Rai, S. (2016). Inhibition of Imiquimodinduced Psoriasislike Dermatitis in Mice by Herbal Extracts from Some Indian Medicinal Plants. Protoplasma, 253(2), 503-515.

Bahraini, P., Rajabi, M., Mansouri, P., Sarafian, G., Chalangari, R., \& Azizian, Z. (2018). Turmeric tonic as a treatment in scalp psoriasis: A randomized placebo-control clinical trial. Journal of Cosmetic Dermatology, 17(3), 461-466.

Bratawidjaja, G. (2000). Imunologi Dasar (4th ed.). Jakarta: Balai Penerbit Fakultas Kedokteran Universitas Indonesia.

Chainani-Wu, N. (2003). Safety and antiinflammatory activity of curcumin: a component of tumeric (Curcuma longa). 
The Journal of Alternative \&

Complementary Medicine, 9(1), 161-168.

Fan, Y.-Y., Huang, Z.-T., Li, L., Wu, M.-H.,

Yu, T., Koup, R. A., ... Wu, C.-Y. (2009).

Characterization of SARS-CoV-specific

memory $\mathrm{T}$ cells from recovered

individuals 4 years after infection.

Archives of Virology, 154(7), 1093-1099.

Frieman, M., Heise, M., \& Baric, R. (2008).

SARS coronavirus and innate immunity.

Virus Research, 133(1), 101-112.

https://doi.org/10.1016/j.virusres.2007.03. 015

Gorbalenya, A. E., Baker, S. C., Baric, R. S., De Groot, R. J., Drosten, C., Gulyaeva, A. A., ... Penzar, D. (2020). The species Severe acute respiratory syndrome-related coronavirus: classifying 2019-nCoV and naming it SARS-CoV-2. Nature Microbiology, 5(4), 536-544. https://doi.org/10.1038/s41564-020-0695$\mathrm{z}$

Huang, C., Wang, Y., Li, X., Ren, L., Zhao, J., $\mathrm{Hu}, \mathrm{Y} .$, ... Cao, B. (2020). Clinical features of patients infected with 2019 novel coronavirus in Wuhan, China. The Lancet, 395(10223), 497-506. https://doi.org/10.1016/S01406736(20)30183-5

Katzung, B. (2002). Farmakologi Dasar dan Klinik. Jakarta: Salemba Merdeka.

Li, X., Geng, M., Peng, Y., Meng, L., \& Lu, S. (2020). Molecular immune pathogenesis and diagnosis of COVID-19. Journal of Pharmaceutical Analysis, 10(2), 102-108. https://doi.org/10.1016/j.jpha.2020.03.001

Riedel, S., Morse, S. A., Mietzner, T. A., \& Miller, S. (2019). Jawetz Melnick \& Adelbergs Medical Microbiology 28 E. New York: McGraw Hill Professional.

Rosiyani, L. (2010). Evalusi Perubahan Metabolit Pada Temulawak Dengan Waktu Tanam Berbeda. Institut Pertanian Bogor.

Siahaan, J. M. (2017). Effect of Antihipoglycemic Sechium edule Jacq. Swartz. Etanol Extract on Histopathologic Changes in Hyperglycemic Mus musculus L. Indonesian Journal of Medicine, 02(02), 86-93.

https://doi.org/10.26911/theijmed.2017.02 .02 .02

Siahaan, J. M., Anto, E. J., \& Fauzi, T. M. (2021). The Effects of Ethanol Extract, Chayote (Sechium Edule (Jacq.) Swartz) Fraction and Juice on the High-density
Lipoprotein Level in Male White Mice.

Indonesian Journal Of Medicine, 6(2), 145-151.

https://doi.org/10.26911/theijmed.2021.06 .02 .03

Sreejayan, N., \& Rao, M. N. A. (1994).

Inhibition of radiation-induced lipid peroxidation by curcumin. Journal of Pharmacy and Pharmacology, 46(12), 1013-1016.

Suhendra, L. (2017). Aktivitas Antioksidan Ekstrak Bubuk Kunyit (Curcuma domestica Val.). Jurnal Ilmiah Teknologi Pertanian AGROTECHNO, 2(2), 237247.

Tjay, T. H., \& Rahardja, K. (2002). Obat-obat penting: khasiat penggunaan dan efekefek sampingnya (5th ed.). Jakarta: Departemen Kesehatan Republik Indonesia.

Wilmana, P. F. (1995). Analgetik Antipiretik Analgetik Anti-inflamasi Non Steroid dan Obat Pirai (4th ed.). Jakarta: Balai Penerbit Fakultas Kedokteran Universitas Indonesia.

Yue, G. G. L., Chan, B. C. L., Hon, P.-M., Lee, M. Y. H., Fung, K.-P., Leung, P.-C., \& Lau, C. B. S. (2010). Evaluation of in vitro anti-proliferative and immunomodulatory activities of compounds isolated from Curcuma longa. Food and Chemical Toxicology, 48(8), 2011-2020. 